\title{
A SELF-STUDY OF PEDAGOGICAL EXPERIENCES IN HISTORY EDUCATION AT A UNIVERSITY DURING THE COVID-19 PANDEMIC
}

DOI: http://dx.doi.org/10.17159/2223-0386/2020/n24a6

\author{
Leevina M Iyer \\ University of KwaZulu-Natal, Pinetown, South Africa \\ iyer@ukzn.ac.za \\ ORCID No.: 0000-0002-2457-7213
}

\section{Abstract}

Educational transformation is an ongoing process. However, in 2020 the transformation in South Africa was accelerated by the COVID-19 pandemic. This global health threat was inadvertently a catalyst for considerable change within the field of education. Considering that the nature of COVID-19 was infectious, the best mode of delivery for education to students during the pandemic was digital platforms. For the History Education department at the University of KwaZulu-Natal (UKZN), this was a significant transition from the conventional contact methods. While digital platforms were used under normal conditions to complement contact lectures, the transition meant that all teaching was completely dependent on digital platforms. Navigating this change was both interesting and challenging for me as a teacher and supervisor of History Education. This paper is a self-study of my experiences of engaging with online History Education at postgraduate and undergraduate levels within Higher Education. History Education modules had to be re-engineered, and pedagogical considerations had to be explored to align with the use of digital software. The online transition was not seamless and was accompanied by challenges that ranged from technological inaccessibility and teacher training for online education to academic disparities. At the onset of the transition, technology proved to exacerbate existing geo-social and educational inequalities within the learning community at the UKZN's History Education department. It undeniably took a considerable amount of time to acclimatise to the new digital platforms for online education. Eventually, there were visible successes. For instance, new online pedagogies proved effective in traversing History Education modules via online education. Training in the use of software and applications was also useful in achieving the learning objectives of History Education modules. Online resources, such as multimedia, were easier to incorporate into History Education lectures. This provided an integrative shift between theory and real-life experiences. Arguably, the COVID-19 pandemic served as a catalyst for embracing digital platforms, which we, as educationalists, 
may not have otherwise implemented were it not a necessity.

Keywords: History Education; COVID-19; Multimodal Model for Online Education; Digital platforms; Higher education; Remote learning; South Africa.

\section{Background}

Comparable with a scene from the 1722 novel, A Journal of the Plague Year by Daniel Defoe, the scenario facing the world in February 2020 was similarly ominous and equally incredulous. The present scenario is a global health threat referred to as the Coronavirus Disease 2019 (COVID-19) and is the cause of an infectious respiratory disease (Fauci, Lane and Redfield, 2020). By 11 March 2020, COVID-19 was declared a global pandemic (World Health Organisation - WHO, 2020). By 27 December 2020, there were 76103 424 global confirmed cases of infected people and 1694717 known deaths (European Centre for Disease Prevention and Control, 2020). Since the virus was infectious, the best mode of educational delivery to students during the pandemic was remote online education through digital platforms.

For the History Education ${ }^{1}$ department at the UKZN this was a significant shift from the conventional contact methods of teaching and learning. Thus, this paper presents a self-study of my personal pedagogical practices and experiences as a teacher within the History Education department during the COVID-19 pandemic. Since there was a gap in literature regarding History Education practitioners' experience during such a global health treat within the context of UKZN, I decided to explore how the pandemic influenced my History Education pedagogical practices in semester one of the academic year 2020 at the University.

During the nation-wide lockdown in South Africa which was enforced on 15 March 2020, the response of the University management, teachers and students were immediate. At the outset of the transition to online education, Higher Education policy-makers and practitioners were designing innovative ways to prepare staff and students to utilise various platforms for remote digital teaching and learning. Consequently, in April 2020, the University held training workshops regarding online software

1 History Education in this paper, refers to History courses taught at the School of Education (Edgewood Campus) which focuses on teacher-training. Issues of pedagogy, methodology and theory of History are taught in History Education. 
such as Moodle, ${ }^{2}$ Microsoft PowerPoint, Zoom, ${ }^{3}$ and Kaltura.${ }^{4}$ While digital platforms such as Microsoft PowerPoint and Moodle were used under normal circumstances by the History Department to complement contact lectures, the pandemic meant that all teaching was entirely dependent on the use of digital platforms. The University purchased software licenses for staff to have access, and data packages were negotiated with four major mobile networks in South Africa for students and staff.

Subsequently, an online educational 'dry-run' was initiated on 18 May 2020 at the UKZN. This dry-run was a two-week period that served as a trial period with which to test the technological systems, such as internet connection and accessibility to software, as well as to acclimatise students to the new digital platforms. History Education courses had to be reengineered to cater to online education. In some cases learning objectives and assessments were modified to suit digital platforms.

Different preliminary initiatives were undertaken to determine initial challenges that students may have regarding online education. For instance, revision activities for History Education courses were uploaded to provide facilitators and practitioners an indication of the level of accessibility and digital skills that students had. This two week grace period greatly assisted the History Education department in that it was discovered that several students had either not received data packages issued by the University at the time, or they did not have stable internet connectivity. This meant that at the very beginning of the transition to online education, technology was exacerbating existing geo-social and educational inequalities within the learning community at the UKZN.

\section{Methodology}

Considering the above context, the overarching research question which guided this study was: how did COVID-19 influence my pedagogical practices of History Education modules in semester one of the academic year 2020? I drew upon the Self-study of Teaching and Teacher Education

2 Moodle is an open source learning platform dedicated to educational content. It promotes collaborative online learning by allowing facilitators to create private online spaces for courses. Courses can be tailored to students due to the free and flexible software available on Moodle (Moodle Pty Ltd, 2020).

3 Zoom is a cloud platform that has features which prove helpful in conducting online education. These features include video, voice and content-sharing. Zoom can be accessed via desktops, mobile devices and telephones (Zoom Video Communications, Inc., 2019).

4 Kaltura is a video platform that promotes education, collaboration, communication and entertainment via video (Kaltura, 2020). 
Practices (S-STEP) methodology. Essentially, the S-STEP methodology examines the teacher as the researcher, and their practices within the educational context (Berry, 2015). I specifically drew upon the S-STEP since it would illustrate my personal pedagogical practices and experiences during COVID-19, a new phenomenon directly influencing my pedagogical practices within the History Education Department at UKZN. In keeping with the S-STEP methodology, this study adopted a qualitative approach and was based on the interpretivist paradigm. The data collection tools that were used for this study were observations (active and moderate), and Journalling.

Fundamental to obtaining first-hand data was for me to be an observer. Given that my focus was on teaching History Education through online education, I chose to engage in participant observation, which is a data collection tool that records and examines the participation of identified people in a naturalistic setting (Musante \& DeWalt, 2010). This meant that I would observe my interactions with my students, as well as their interaction and behaviour with the digital content material. Through participant observations, I identified, deconstructed, and interpreted aspects of using online education to teach my History Education modules.

Furthermore, I engaged in journalling, which according to Pinnegar and Hamilton (2009), can be considered an all-encompassing activity in that, through writing, the researcher can freely express themselves in terms of professional, pedagogical and personal aspects. Additionally, journalling shows the progression of ideas, as well as recording experiences which can then be interpreted and improved (Luescher, 2016). Using journalling as a research strategy enabled me to actively engage with my pedagogy and personal ideas. It enabled me to deconstruct ideas that I otherwise would not have considered exploring.

\section{Pedagogical considerations for my History Education modules}

The Multimodal Model for Online Education, hereafter MMOE (Picciano, 2017), was used as a pedagogical approach for my History Education modules, and served as the theoretical framework for this study. This Model is an integrated construction that considers several essential aspects of online education, including students' conceptual, social, and emotional needs (refer to Image 1). The learning community involves teachers and students, and I have found that the MMOE encapsulates the role of and 
impartially caters to university teachers and students (in-service and preservice teachers) within History Education.

Image 1: Multimodal model for online education (author's adaptation of Picciano's original model)

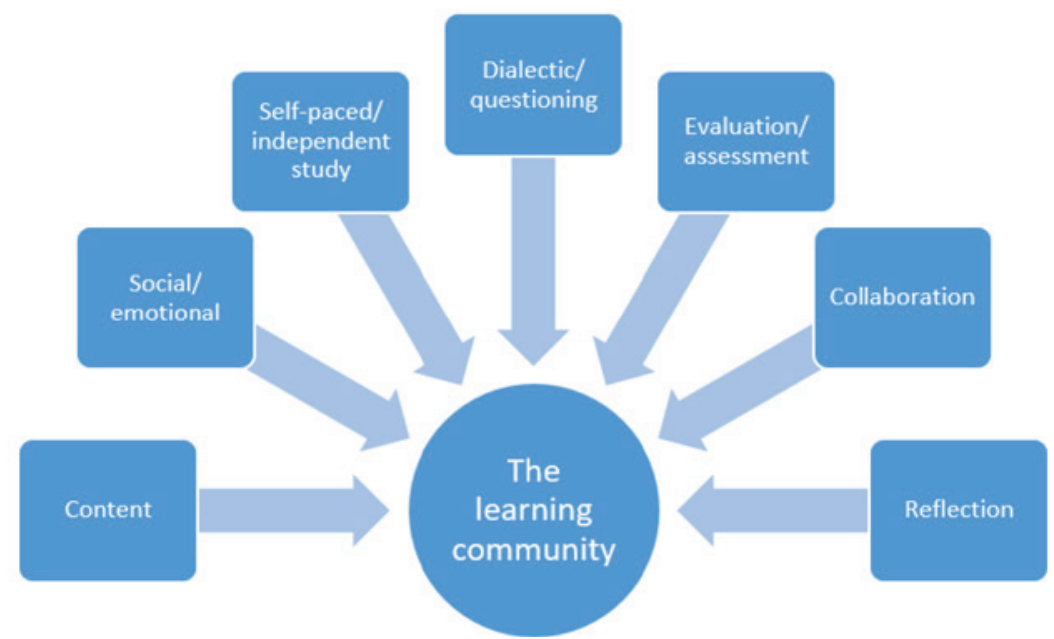

Source: AG Picciano, "Theories and frameworks for online education: Seeking an integrated model”, Online Learning, 21(3), DOI: 10.24059/olj.v21i3.1225, 2017, pp. 166-190.

There are essentially seven elements that construct the MMOE. These elements will be discussed below to provide a conceptual understanding of the Model. Thereafter, I will provide examples of how I applied the MMOE in my History Education modules to explicate how these elements were used.

To begin with, the content is fundamentally module-related. The module's learning objectives can guide teachers on what content to develop and make available to students. Content can be presented in the forms of literature, readings, notes, as well as more interactive and visually stimulating resources such as videos, interview recordings, images and games.

Moreover, while it is essential to deliver instructional content, it is equally important to consider students' social and emotional wellbeing. In a time when a pandemic threatens the world, students may be ill-equipped to deal with the emotional, social, and educational demands placed on them. Therefore it is essential to provide them with mental stability in an academic context. The presence of the teacher and other students may offer some such form of stability. This can be achieved through same-time 
applications such as Zoom, Skype, emails or any other real-time interface.

Although direct teacher instruction can significantly help facilitate students' understanding of content, students should be given opportunities to develop their understanding through self-paced/independent study. Cervetti, Damico and Pearson (2006) assert that multimodal online education is a social practice as much as it is a skills-based medium. This means that students must learn how to use online tools to be actively involved in tasks.

Further, dialectic questioning is an integral part of the educational process. This stimulates critical and independent thinking, and is a way to see if students understand and can apply the content that is facilitated in the module. This could be as part of an assessment that will carry marks, or it could be activities that entail students having to discuss their thoughts. Discussion boards are great for developing independent thinking (Picciano, 2007). They also allow students to view and respond to each other's comments and questions, and create active student participation that also increases engagement with and interest in the content of the module.

Essentially, evaluation and assessment is another fundamental practice in the educational process. Teachers need to assess whether or not students have been able to meet the learning objectives and understand the content of the module. There are several ways of evaluating and assessing students' progress. While essays, tests, and typed work can still be used, online assessments are typically becoming more creative than the traditional paper-based assessments. Examples of such online assessments include multimedia-based activities such as videos, digital images, podcasts, discussion boards, and so on.

In effect, collaboration and student-generated content is an essential factor in MMOE. Gee (2004:79), explains that an "affinity space" is ultimately created through online education. This means that students come together with a common objective primarily through the use of technological tools such as the Internet, games and threads, among others. Through active participatory tasks, students foster a collaborative environment in which they support each other's educational progress. Examples of collaborative online tools include group portfolios, multimedia projects, wiki pages, and group support mechanisms.

Lastly, as much as it is imperative for dialogue between students and the teacher and between students, it is also vital for students to reflect 
on their educational progress. Reflecting on one's work is primarily an inward evaluation process (Cambra-Fierro \& Cambra-Berdún, 2007). Through the process of reflection, students discover what they know, and more importantly, what they would like to know. This develops critical, independent thinking. Students can be encouraged to keep a digital journal or partake in discussion boards and blogs. By sharing their reflection with their peers, they can create an environment of critical thinking. Multifarious perspectives and common views are challenged through collaboration and self-reflection.

\section{Application of the MMOE in my History Education modules}

While the MMOE contained several essential aspects of students' educational and social needs, I omitted some elements included in the Model depending on the nature of my History Education modules. In effect, due to the diverse learning objectives and class dynamics of my modules, I used the various elements of the Model differently and tailored the modules accordingly. Two examples of how I applied the MMOE are provided below.

\section{Undergraduate History Education module}

This module principally dealt with topics of prejudice and wars. Issues of prejudice are regarded as an integral part of History, particularly regarding the South African past. Thus this module aimed to empower History Education students to teach themes from modern History. At the end of the module, the students should have developed a sound knowledge base and understanding of theoretical principles of History and be able to apply this specific knowledge in context.

The learning objectives for this module expected the student to be able to:

- demonstrate a conceptual understanding of the relationship between prejudice and the historical events that shaped the modern world;

- critically evaluate and use historical evidence related to modern History;

- exhibit a historical imagination;

- debate conflicting and controversial Historical interpretations of modern History;

- recognise that different value systems and traditions influenced the way the history of the world is interpreted. 
Given that this class consisted mostly of first and second-year students, social media, such as Instagram, Twitter, and Facebook, were used to pique their interest in the content of the module. Students were encouraged to follow people, groups, or pages that focused on topics of prejudice and wars to develop a sense of the various historiographies that exist regarding these topics. Students were then asked to share these with the rest of the class so that everyone could view the content/ discussion of the relevant post. This aided in their understanding of the fluid nature of historical interpretations while drawing on historical evidence.

Hyperlinks to History videos ${ }^{5}$ and articles $^{6}$ that related to the content were made available on Moodle and WhatsApp. These documentaries often had interviews with people who were experts in the field of History and who explained the concept under study. This meant that, while students were not given the opportunity to have guest lecturers, they were exposed to experts in the field. The above resources facilitated students' engagement with historical concepts such as causation, historical significance and historical consciousness in the modern world, which manifested in the topics of prejudice and wars.

Further, Moodle chats and WhatsApp discussions were primarily used to promote a collaborative learning environment. Questions were posed to students, or scenarios were provided. Students were then required to comment on these questions and scenarios. This served three-fold objectives: firstly, it prompted collaborative discussions and promoted multiperspectivity in historical thinking; secondly, it required students to reflect on their own views; lastly, the class consisted of over 270 students, thus these discussions helped evaluate the progress of students' historical consciousness through their responses.

Due to the transition from contact lectures to online education, formative assessment was used instead of summative assessment. Assessment for this module consisted of an academic essay, an Op-Ed and a test. The

5 Examples used in this module: (a) E Blakemore, "The harsh reality of life under apartheid in South Africa", 2019 (available at https://www.history.com/news/apartheid-policies-photos-nelson-mandela, as accessed on 7 August 2020); (b) Anon., Discovery Science, "Darwin, Africa, and genocide: The horror of scientific racism", 2020 (available at https://www.youtube.com/watch?v=1QPrvPM38Ws, as accessed on 20 July 2020).

6 Examples used in this module: (a) E Blakemore, "Human migration sparked by wars, disasters, and now climate", 2019 (available at https://www.nationalgeographic.com/culture/topics/reference/migration/, as accessed on 4 September 2020); (b) Anon., "Black and Scottish: 'Are you a Protestant Rasta or a Catholic Rasta?'”, 2019 (available at https://www.bbc.com/news/uk-scotland-49894363, as accessed on 20 July 2020); (c) G Timmons, "How slavery became the economic engine of the South", 2018 (available at https:// www.history.com/news/slavery-profitable-southern-economy, as accessed on 20 July 2020). 
essay required students to critically discuss the influence of traditional and contemporary media on intensifying women's rights in present-day society. Students could draw upon national and international examples. The question for the Op-Ed required students to reflect on the on-going xenophobic attacks in South Africa as a lived example of present-day prejudice. Furthermore, the usual module examination was replaced with an online test that consisted of two paragraph questions and short answer questions. These assignments were designed such that they would help students achieve the learning objectives of this particular module (outlined above). Essentially, the assessments evaluated students' levels of historical understanding and ability to form critical, evidence-based arguments.

Continuous assessments were also assigned to students which served as revision activities, as well as provided feedback on the level of historical understanding that each student had. Examples of these assessments included multiple choice quizzes, short documentary studies, reading reports and discussion boards. These concise activities were directly aligned to the learning objectives of this module and simultaneously accommodated the MMOE. Thus, these assessments evaluated the students' conceptual understanding of the relationship between prejudice and the historical events that shaped the modern world.

In essence, this module was structured in a way that required increased autonomy of students, whilst also providing collaborative opportunities for them to work together.

\section{History Education Honours module}

Three key elements of post-graduate studies - theory, policy, and research - were used to inform this module. The focus of the module was to provide a theoretical and conceptual understanding of issues in teaching History Education through film and Information and Communications Technology (ICT). Students were exposed to relevant theories and practices by analysing the use of film and ICT as powerful tools in History Education.

The students in this Honours module would have already completed the compulsory History Education modules as part of their undergraduate degree in Education, and therefore the purpose of this module was to extend their theoretical knowledge-base to classroom practice. 
The learning objectives for this module were for students to:

- Demonstrate an understanding of the possibilities film and ICT offer to History Education;

- Critique issues related to the use of film and ICT in History Education;

- Initiate educational strategies in order to enhance the use of film and ICT in History Education;

- Demonstrate the ability to make a short educational history-related film.

No alterations were made to the above objectives from the previous year, as students could achieve these objectives through online education. Additionally since the nature of the module was based on the use of film and ICT to teach History, digital learning was a great way to practise what they learnt during the course of the module. For this module, all the elements included in the MMOE were used.

PowerPoint presentations with voice-over narration were made available to students. These presentations facilitated the theoretical and conceptual underpinnings of the use of film and ICT in History Education. By including the voice-over narration, this created the illusion of being in a class-based face-to-face lecture. In-depth elucidations of content were included to achieve a level of clarity and understanding of historical didactics. Following the upload of these recorded lectures, questions were posed to students. Discussion boards and chats on Moodle and WhatsApp were used as a platform for reflective and collaborative participation. One such discussion was based on the implications of visual culture on the teaching and learning of History.

Additionally, owing to the fact that the class size was relatively small (35 students), synchronous lectures were held via Zoom. These lectures were more interactive than the PowerPoint presentations due to the same-time interaction. Students were able to actively engage with the content, and discussions ${ }^{7}$ were held synchronously. These Zoom lectures were recorded

7 Examples used in this module: (a)=Anon., TEDx Talks, "Teaching history in the 21st century: Thomas Ketchell at TEDxLiege", 2014 (available at https://youtu.be/8eIvGtn1NAU, as accessed on 18 April 2020); (b) Anon., TEDx Talks, "Re-inventing education for the digital age | David Middelbeck | TEDxMünster", 2019 (available at https://www.youtube.com/watch?v=ArI6albrkuY, as accessed on 22 April 2020); (c) ES van Eeden, "Thoughts about the historiography of veracity or truthfulness in understanding and teaching History in South Africa", Yesterday and Today, 15, 2016 (available at www.scielo.org.za/scielo. php?script=sci_arttext\&pid=S2223-03862016000100004. d, as accessed on 15 May 2020), pp. 37-65; JD Stoddard and AS Marcus, "More than showing what happened: Exploring the potential of teaching history with film", The High School Journal, 93(2), 2010 (available at scholarworks.wm.edu/cgi/viewcontent.cgi? article $=1113 \&$ context=educationpubs, as accessed on 8 March 2019), pp. 83-90. 
and subsequently uploaded onto Moodle for future reference, as well as to be accessed by students who were unable to attend the Zoom lectures.

Scholarly readings and additional sources of information pertaining to film and ICT in History Education were either uploaded onto Moodle, or hyperlinks were made available to students to provide a theoretical base, as well as to strengthen their conceptual understanding of content. The readings also served to help develop their independent critical historical thinking skills and to enhance multiperspectivity by exposing them to various views related to the content.

Assessment for this module was essentially a combination of traditional assignments: an academic essay and reading reports; together with multimedia projects: a digital portfolio and production of a short film. The academic essay required students to critically discuss cultural, psychological and emotional impacts of using ICT to teach History to learners from disadvantaged communities in South Africa. This question allowed students to critique issues related to the use of ICT in History Education.

The production of a short film principally served as a digital narrative to enhance historical consciousness in a modern setting. Students had to produce a film based on the Mineral Revolution in South Africa using software such as Windows MovieMaker, Microsoft PowerPoint, Photos Application, GoPro Quik, Filmora9, and so forth. Thereafter, History Education seminars were held via Zoom in which each student was given 15 minutes to present their film. Thereafter a 'question and answer' session took place, and discussions were held about the content and production of the video.

Students were given the option to upload their videos to YouTube. This made their video available to their colleagues at work and other History teachers, who had no access to the Moodle website. Students and colleagues who watched the videos were able to comment on the content. In some instances, students who produced the film granted permission to other students and colleagues to show the film during the History lesson at school. Effectually, these seminars allowed for collaboration as well as social interaction between students within an academic setting with a focus on History methodology. 
Ultimately, the MMOE provided a theoretical and pedagogical framework for my History Education modules. The Model propounded essential aspects of online education that ranged from academic considerations to the emotional and social needs of students. The subsequent section will present a discussion of my professional and personal experiences with the transition from contact sessions to digital remote online education.

\section{Discussion}

My role in the History Education department was multifaceted. I was the co-ordinator ${ }^{8}$ of four History Education undergraduate modules and one Honours module. I also supervised Masters and Honours students with their dissertations and research projects. Initially I greatly anticipated the transition from contact lectures to digital platforms. As a teacher belonging to Generation Y, I was keen on using, and acquainting my students to technology that would be beneficial to their teaching. Now that my History Education students were required to use technology as an educational platform, I was optimistic that they would be well-equipped for teaching in a world that was operating on the border of the fourth and fifth digital revolutions. Knowing that my History Education students were on a similar educational arena as the rest of the world, gave me a sense of hope that they would not be disadvantaged because of their lack of skills-based knowledge and practice.

Despite my initial anticipation of successful integration to online education, I was soon overwhelmed with challenges that were beyond my control. First and foremost was the challenge of communicating with students. Due to the national lockdown in South Africa in March 2020, a large number of History Education students had to move back to their homes, many of whom lived in areas that had inadequate/ no internet connectivity. While data was provided to students by the University, many students experienced technical issues such as slow/ no internet connection. Additionally, students who were accustomed to working in the University campus LANs now had to obtain the necessary equipment (hardware and software) to access their work. Moreover, some students experienced skills-based challenges in that they did not know how to use software such as Dropbox and Zoom, or complete activities on Moodle (Hoskins, 2020).

8 My role of module co-ordinator included developing course content, creating assessment tasks and rubrics, setting-up Teaching and Learning pages and selecting digital platforms for each of my History Education modules. 
Furthermore, Moodle was to be the chief platform for communication with students. However, due to technical issues, students requested that WhatsApp be used for academic communication. Eventually, WhatsApp groups were created, and students were sent a link to click on to join the relevant module group. The same material that was uploaded onto Moodle was sent to students via WhatsApp. However, some resources were programmed on Moodle that could not be accessed elsewhere, such as Moodle chats, Moodle quizzes, Moodle journals, Moodle lessons, as well as dissemination of academic materials. This disadvantaged students who could not access Moodle, and in turn resulted in a cascading effect, i.e. these students were unable to access the material or complete assessments that were Moodle-based. This meant that they would automatically fail the assessment and this would significantly impact their final mark.

Further compromising the History Education modules was the issue of assessment. Prior to the transition to digital education, students submitted printed assessments. I felt that marking was easier when I used a pen to write comments. With digital education, students submitted their assessments via Moodle or Dropbox. This proved as a challenge for me since having to type out comments and indicating marks using the 'track changes' function was increasingly time-consuming - especially when my cursor jumped to different places of the document and my noting this only after having typed a comment for two minutes. I felt this exceedingly frustrating and longed for the traditional printed submissions, and pen marks on my fingers.

Having said that, I did appreciate the convenience of softcopy versions of assessments when detecting plagiarism. Turnitin is the University's assigned plagiarism identification software. However due to the large amounts of submissions, or expired University licences, Turnitin was often unavailable. I found that there was indeed, an increase of plagiarised submissions in comparison to the year 2019, especially with the first-year History Education modules.

Another key challenge was the disinclination of my History Education tutors $^{9}$ to engage with digital platforms. Two of the three tutors distinctly displayed their unwillingness to engage with digital education. Various

9 I am currently a PhD candidate involved in UKZN's University Staff Development Programme (USDP). As part of the conditions of this programme, contract staff were appointed to assist me with my History Education modules. Whilst I developed content and assessment for the modules, my tutors were responsible for delivering the lectures, marking, and working with the Administrative Offices to ensure correct capturing of marks. Ultimately, the modules remained under my full responsibility and I was accountable for content, assessment and student engagement in my History Education modules. 
factors could have attributed to this reluctance to use technology as a medium of education. These factors range from age, pedagogical preference towards traditional face-to-face interactions, little or no training in the digital platforms being used for online education, no experience with applications and programmes, as well as lack of intrinsic motivation (Duong, 2019; Downing \& Dyment, 2013; Stewart, Bachman \& Johnson, 2010).

Bearing the above challenges in mind, I often felt deflated and despondent - both physically and psychologically. Nevertheless, I knew that this feeling was possibly shared by my colleagues and my History Education students. My only option was to revive my frame of mind, and gather motivation by speaking to colleagues and attending to one challenge at a time. Consequently, the following section discusses my attempts to overcome or minimise the risk factors of the challenges that would negatively impact my History Education modules.

\section{Dealing with the challenges}

I was particularly concerned about students whose data packages had not been delivered timeously. They would lose an opportunity to engage with important activities and lectures and this would be considerably detrimental to their success of the module. Thus, to ensure that all students received material for my History Education modules, recorded lectures, voice-over PowerPoints, and recording of Zoom interactions were all uploaded so that whenever the students received their data, they could access the material and lectures.

Further, assistance was provided to History Education students who did not have the necessary technical skills to effectively complete tasks, by in-depth point-by-point instructions. Additionally, written instructions were accompanied by screenshots so that students knew exactly what to look for. These instructions were uploaded on Moodle and posted in the WhatsApp group for the relevant History Education modules.

In an attempt to ascertain plagiarised submissions, I copied phrases or sentences from assessments and pasted it on an internet search engine. If there was evidence of plagiarism, I copied the URL of the website from which the work was taken and pasted it as a comment highlighting the plagiarised portions in the document. Nonetheless, this method of identifying plagiarism is restricted because students may have used material that are not electronically captured and will therefore not be found 
on the internet.

To overcome the challenge of the reluctant tutors who assisted with my History Education modules, I chose three key platforms used to communicate with them. These platforms were the UKZN email, Zoom, and WhatsApp. I held weekly Zoom meetings with each tutor in which I discussed the teaching schedule together with the online digital platform $/ \mathrm{s}$ that would be used to teach each History lesson based on the learning objectives for each session. I provided clarity on individual lesson objectives, as well as why particular platforms would be used primarily aligned with the relevant content or assessment. For example, WhatsApp would be the best suited platform when debating a topic which aligned with the learning objective that required students to recognise that different value systems and traditions influenced the way the history of the world is interpreted.

Moreover, I encouraged tutors to attend the webinars and training sessions related to the different online educational platforms that were provided by the University. These workshops included topics such as Navigating online teaching \& learning, Manipulating Moodle to design continuous assessment and Recognition of student diversity and learning styles. I personally found that these online training workshops on the use of different software and applications proved helpful as I learnt to creatively manoeuvre digital platforms to help students effectively achieve the learning objectives of the History Education modules.

In addition to sending teaching material, I also used WhatsApp to send my tutors screenshots of relevant emails that related to issues of teaching and learning. I also sent them screenshots of emails that I addressed to them regarding module-related information as a way to ensure they did receive the communication.

As supervisor of History Education Honours and Masters students, I also experienced challenges. These ranged from domestic to technologyrelated issues. Supervision meetings were held via Zoom, which was the University's preferred platform for Audio-Visual consultations. Only two of my three Masters students were able to attend these Zoom meetings. During these meetings, we experienced further difficulties. For example, one student lived in an overcrowded household, and while we were discussing her work, she had to comfort her sister's crying baby. The meeting was paused numerous times, and eventually, I had to send her the 
feedback via email. The other student had similar issues with his attention being given to his children rather than focusing on our meeting. Internet connection also proved to be an issue where the video would freeze, and we would have to repeat what was already spoken.

As a solution to the predicament mentioned above, I recorded the supervision meetings held on Zoom. Thereafter, I emailed the students minutes of our meeting detailing conversations about their study, as well as the recording of the session. This served as a visual and literary supplement to the discussions, which could have easily been forgotten or misunderstood by students and myself. It also helped serve as a reference point for students should there be a need to consult what we had discussed.

Further, Zoom was useful in that documents could be viewed synchronously through the 'share screen' option, and discussions could occur instantly, creating a live feed to all attendees. This was particularly important during my supervision and History Education discipline meetings, where it was necessary to ensure that everyone was referring to the same points of discussion.

In spite of my great deal of effort to minimise the technical and academic challenges caused by the COVID-19 pandemic, the History Education students still faced their own personal challenges. For instance, some students had contracted the virus, and others had to take care of their loved ones who had the virus. For this reason, provisions were made for students who were directly affected by the pandemic and who did not pass my History Education modules. These students were allocated a CR/F code ${ }^{10}$ on the mark sheet. On 19 October 2020, a Catch-Up Plan was disseminated on behalf of College Dean of Teaching and Learning. The objective of this Plan was to provide an opportunity to affected students to pass the module. The Catch-Up Plan entailed giving the students assessments that could determine their historical literacy of the respective History Education modules.

Whilst the Catch-Up Plan was a good way to cater for students who were disadvantaged by COVID-19 related issues, there were negative implications. Essentially, the Plan was a spill-over into the second semester and this increased my workload. I had to grapple with my second semester modules, while concurrently developing and offering additional support for

10 The CR/F Code refers to students who were directly affected by the COVID-19 pandemic and were unable to complete all assessments for the relevant History Education modules, as well as those who failed the module. 
the History Education students from the first semester, as well as supervise. Moreover, I did this while working on my $\mathrm{PhD}$ study and contributing to the scholarly community. All this proved to be a colossal feat.

Fundamentally, my responsibility as a teacher in Higher Education is to effectively facilitate the historical consciousness and Historyrelated methodologies of my History Education students. I concurrently acknowledge that as an academic I have a duty to share my research with my fellow History Education scholars. For this reason, I made a list of the teaching and academic tasks that I had to complete. I then tried to manage my time accordingly. Priority was given to tasks according to deadlines and submission dates.

Over the period of teaching History Education online, I have learnt to address challenges that threatened the success of my History Education modules. Even though I was dispirited and frustrated at times, I discovered ways to manage my modules such that they would enhance History Education for my students. Ultimately, I fully support the use of online education to teach History Education at tertiary level. And even though I have a considerable amount of technical and skills-based knowledge to master regarding online education, I am certain that there will be a favourable outcome if there is co-operation and mutual collaboration between History teachers and students.

\section{Conclusion}

Arguably, the COVID-19 pandemic has accelerated educational restructuring in South African Higher Education Institutions. In my capacity as teacher and supervisor of History Education at UKZN, I felt that the transition from face-to-face contact teaching to digital online education resulted in a myriad of experiences. I was primarily eager that my students and I would relish the opportunity of technologically empowering ourselves with the use of current software and applications. However, it soon became apparent that both the students and I had challenges. These challenges ranged from technical issues and skills-based incapacities to academic disparities.

Nevertheless, despite the initial challenges of transitioning History Education modules into the digital platform, there were significant achievements. For instance, in the process of setting-up online education, new teaching resources and theories were embraced. For my History 
Education modules, I used the Multimodal Model for Online Education (MMOE) as the basis of my pedagogical approach. Through this Model, I was able to highlight the key aspects of online education, as well as identify significant influencers of students' success. Moreover, teaching became considerably more creative with the use of multimedia resources, which may not have been easily incorporated into face-to-face lectures.

Furthermore, tutors and students did eventually go the extra mile to ensure that the new online pedagogies would prove to be a meaningful experience. Tutors began to understand the importance of constantly providing guidance to students regarding the content as well as explaining ways to navigate the different platforms for accessing and submitting material for respective History Education modules. In the same light, students displayed an understanding of working autonomously to engage with readings, online activities and to complete assessments.

Online education did limit student-teacher, and student-student engagement; and the challenge of broadening educational inequalities through technology is one which must still be addressed. That being said, the digital platforms were creatively utilized to provide a space for collaboration and discussion of topics within History Education modules. It was crucial to keep students mentally stimulated and educationally grounded, especially during a trying time like the COVID-19 pandemic, and online education helped achieve this.

In effect, the role of History Education is to facilitate the growth of students into critically engaged scholars who have developed a historical consciousness, and who can, in turn, teach school learners to embrace the History discipline. I contend that, through online education, History preservice teachers can become more empowered and, if they know how to effectively engage with online education, then they will be equipped to teach History in the school setting.

My recommendation to History teachers is that when using online education it is imperative to attend workshops or enrol in courses that focus on online teaching and learning. Familiarity with the features of the relevant software and applications can best equip them with how to plan their History lessons accordingly. In the same token, it is important to equip History students with the knowledge of how to operate the necessary digital platforms required for their participation and completion of assessments. This can be achieved by providing them with explicit instructions. While there are emerging creative 
ways to actively engage History students, we must keep a watchful eye on issues of plagiarism and academic negligence. Managing History through online education is challenging on one hand, but it can also be a fulfilling information-driven experience for History teachers and students.

\section{References}

Berry A 2015. Self-study of teacher education practices (S-STEP). In: R Gunstone (Ed.), Encyclopedia of science education. Springer, Dordrecht.

Cambra-Fierro, J \& Cambra-Berdún, J 2007. Students' self-evaluation and reflection (part 2): An empirical study. Education+Training, 49(2):103-111.

Cervetti, G, Damico, J \& Pearson, PD 2006. Multiple literacies, new literacies, and teacher education. Theory into Practice, 45(4):378-386.

Department of Health 2020. Media Statement - 10th March 2020 [press release], 9 March 2020. Available at https://sacoronavirus.co.za/2020/03/10/media-statement10th-march-2020/. Accessed on 19 June 2020

Department of Telecommunications and Postal Services 2016. National Integrated ICT Policy White Paper. RSA: Government Printers. Available at https:// www.dtps.gov.za/images/phocagallery/Popular_Topic_Pictures/National_ Integrated_ICT_Policy_White.pdf. Accessed on 18 June 2020.

Department of Transport 2020. Government Gazette - 26 March 2020. Available at https://www.gov.za/sites/default/files/gcis_document/202003/43157rg1106 5gon412.pdf. Accessed on 20 June 2020.

Downing, JJ \& Dyment, JE 2013. Teacher educators' readiness, preparation, and perceptions of preparing preservice teachers in a fully online environment: An exploratory study. The Teacher Educator, 48(2):96-109.

Duong, CD 2019. Perspectives of lecturers' beliefs on integrating information communication technology into e-learning system. Journal of Science Ho Chi Minh City Open University, 9(1):9-23.

European Centre for Disease Prevention and Control 2020. COVID-19 situation update worldwide, as of 23 June 2020. Available at https://www.ecdc.europa.eu/en/ geographical-distribution-2019-ncov-cases. Accessed on 10 October 2020.

Fauci, AS, Lane, HC \& Redfield, RR 2020. Covid-19 - Navigating the Uncharted. The New England Journal of Medicine, 382(13):1268-1269.

Gee, JP 2004. Situated language and learning: A critique of traditional schooling. Psychology Press.

Kaltura 2020. About Kaltura. Available at https://corp.kaltura.com/. Accessed on 18 June 2020. 
Moodle Pty Ltd. 2020. About Moodle. Available at https://moodle.com/about/. Accessed on 18 June 2020.

Musante, K \& DeWalt, BR 2010. Participant observation: A guide for fieldworkers. Rowman Altamira.

National Institute of Allergy and Infectious Diseases 2020. COVID-19, MERS \& SARS. Available at https://www.niaid.nih.gov/diseases-conditions/covid-19. Accessed on 11 June 2020.

Picciano, AG 2009. Blending with purpose: The multimodal model. Journal of asynchronous learning networks, 13(1):7-18.

Picciano, AG 2017. Theories and frameworks for online education: Seeking an integrated model. Online Learning, 21(3):166-190.

Pinnegar, S \& Hamilton, ML 2009. Self-study of practice as a genre of qualitative research: Theory, methodology, and practice, 8. Springer Science \& Business Media.

Ramaphosa, C 2020. Statement by President Cyril Ramaphosa on measures to combat COVID-19 epidemic, [press release], 15 March 2020. Available at https:// sacoronavirus.co.za/2020/03/15/statement-by-president-cyril-ramaphosaon-measures-to-combat-covid-19-epidemic/. Accessed on 19 June 2020

Stewart, C, Bachman, C \& Johnson, R 2010. Predictors of faculty acceptance of online education. MERLOT Journal of Online Learning and Teaching, 6(3):597-616.

World Health Organisation 2020. WHO Timeline - COVID-19. Available at https://www. who.int/news-room/detail/27-04-2020-who-timeline---covid-19. Accessed on 19 June 2020.

Zoom Video Communications, Inc. 2019. About Zoom. Available at https://www.zoom. us/about. Accessed on 18 June 2020. 